\title{
Response of weed flora to conservation agriculture systems and weeding intensity in semi-arid Zimbabwe
}

\author{
Nester Mashingaidze $^{1 \star}$, Ignacio Casper Madakadze ${ }^{1}$ and Stephen Twomlow ${ }^{2,3}$ \\ ${ }^{1}$ Department of Plant Production and Soil Science, Faculty of Natural and Agricultural Sciences, University of Pretoria, \\ Pretoria 0002, South Africa. \\ ${ }^{2}$ International Crops Research Institute for the Semi-Arid Tropics, Matopos Research Station, P. O. Box 776, Bulawayo, \\ Zimbabwe. \\ ${ }^{3}$ IFAD Regional Office in Nairobi, C/O Union, UN Avenue, Kenya.
}

Accepted 6 April, 2012

\begin{abstract}
A field study was conducted in the fifth (cowpea crop) and sixth (sorghum crop) seasons of a long-term conservation agriculture trial at Matopos Research Station to determine the effect of tillage, maize mulch rates and intensity of hoe weeding on weed density and community diversity. The experiment was a split-plot randomized complete block design with three replications. Tillage was the main plot factor; conventional tillage versus the minimum tillage (MT) systems of ripper tine and planting basins. Maize mulch rate $\left(0,4\right.$ and $\left.8 \mathrm{tha}^{-1}\right)$ was the sub-plot factor to which was super-imposed the intensity of hoe weeding treatment (low and high) as from the fifth season. Tillage system had no significant $(P<0.05)$ effect on weed density and diversity. Whereas the maize mulch rate of $4 \mathrm{t} \mathrm{ha}^{-1}$ increased weed density in both crops, the mulch rate of $8 \mathrm{t} \mathrm{ha}^{-1}$ decreased the density of Portulaca oleracea and Corchorus tridens in sorghum. Weed density was lower and community diversity higher in the high than the low weeding intensity treatment in sorghum. Although, frequent hoe weeding can be used to control weeds in MT systems, labour shortages may ultimately limit the area under MT in smallholder agriculture.
\end{abstract}

Key words: Tillage, maize mulch, weed density, community diversity, cowpea (Vigna unguiculata (L.) Walp.), sorghum (Sorghum bicolor (L.) Moench).

\section{INTRODUCTION}

The major biophysical constraints to rainfed crop production in the semi-arid areas of southern Africa are unreliable rainfall and infertile soils (Twomlow et al., 2006) with smallholder productivity further limited by poor crop management practices (Sanchez, 2002). Conservation agriculture $(\mathrm{CA})$ based on the principles of minimum tillage, permanent organic soil cover and crop rotation is being currently promoted to smallholder farmers in southern Africa to increase productivity levels (FAO, 2010). Although, the majority of smallholder farmers face constraints in implementing full CA (Giller et al., 2009), there is increasing evidence that higher and

*Corresponding author. E-mail: nestermash@yahoo.com. Tel: +263712933329. more stable crop yields are being obtained in fields under minimum tillage compared to conventional ploughing (Wall, 2007). The minimum tillage systems of planting basin and ripper tines increased yield in semi-arid areas by enabling farmers with limited draught animal power to plant early, to use scarce soil fertility amendments more efficiently through precision application and to carry out timely crop management (Twomlow et al., 2009). However, the area under minimum tillage systems in southern Africa still remains low (Derpsch and Friedrich, 2009) with many arguing that the impacts of $C A$ on crop production are extremely variable, dependent on soil type, crops and the initial weed infestation (Farooq et al., 2011; Gowing and Palmer, 2008; Giller et al., 2009).

Farooq et al. (2011) content that integrated weed management is the fourth component/principle of successful CA. This is because weed control is identified 
as the biggest and often most difficult challenge in management faced by farmers that adopt minimum tillage (Gowing and Palmer, 2008). In fact, in smallholder agriculture in Zimbabwe, conventional tillage such as mould board ploughing in early summer is considered a major weed control technique that prepares a weed-free seedbed for up to four weeks (Mabasa et al., 1998). Chauhan et al. (2006) reviewed tillage research mostly done in temperate regions and found that minimum tillage systems had higher weed density compared to conventional tillage. There is, also, mounting evidence of increased weed density under minimum tillage systems from research done in sub-Saharan Africa (Mabasa et al., 1998; Baudron et al., 2007). Furthermore, studies of minimum tillage systems indicated higher densities of perennial weed species in Zimbabwe (Vogel, 1994; Makanganise et al., 2001) compared to conventional tillage. These shifts to new and possibly more difficult to control weed species under minimum tillage systems is probably limiting the widespread uptake of CA by resource-poor farmers in Africa.

The adoption of minimum tillage has been mainly facilitated by the use of herbicides in developed countries and within the commercial farming sector in southern Africa (Wall, 2007). However, the affordability and availability of suitable herbicides limit their use in the smallholder farming sector of southern Africa (Giller et al., 2009). The majority of smallholder farmers use hand hoes to weed arable fields, a method that is slow, labour-intensive and associated with drudgery (Twomlow et al., 2006). Hoe weeding often results in a decrease in crop yield due to delayed weeding as labour is often unavailable during critical weeding periods (Gianessi, 2009). Consequently, the reported increases in labour required for hoe weeding crops under planting basins in Zambia (Baudron et al., 2007) and (Mazvimavi and Twomlow 2009), suggest that such minimum tillage systems are likely to exacerbate pre-existing weed control problems in the smallholder sector (Vogel, 1994). Since weed competition is one of the most serious and widespread problems (Gianessi, 2009) with weeds consistently ranked as the number one pest by smallholder farmers in sub-Saharan Africa (Sibuga, 1997), there is need to identify effective weed management strategies for use under smallholder minimum tillage systems if they are to be successfully promoted.

According to Wall (2007) and FAO (2010), weed control under CA is difficult only in the first years and becomes easier over time with good management. However, the 'good weed management' being referred to is achieved mainly through the use of herbicides (Wall, 2007). Although, the CA practices of crop residue mulching and crop rotation are reported to ameliorate weed problems under minimum tillage systems and lead to more sustainable weed management in the long-term (Wall, 2007; FAO, 2010), evidence of this from southern Africa is sparse and inconclusive (Gowing and Palmer, 2008; Giller et al., 2009). The aim of this study was to investigate the effects of tillage system, hoe weeding intensity and maize residue mulching on weed flora composition in the fifth and sixth years of a CA experiment in semi-arid Zimbabwe.

\section{MATERIALS AND METHODS}

\section{Location}

The field experiment was conducted at West Acre Creek of Matopos Research Station Farm (28 $30.92^{`} \mathrm{E}, 2^{\circ} 0^{\circ} 23.32 ` \mathrm{~S} ; 1344$ $\mathrm{m}$ above sea level) in southwestern Zimbabwe. The station is characterized by semi-arid climatic conditions $\left(25.5^{\circ} \mathrm{C}\right.$ average maximum and $10.7^{\circ} \mathrm{C}$ average minimum temperatures; and mean annual rainfall of $580 \mathrm{~mm}$ ). The wet season is mainly confined to the period between November and March. The soil is a ChromicLeptic Cambisol according to the FAO classification (Moyo, 2001) with a clay loam texture ( $41 \%$ clay, $20 \%$ silt, $38 \%$ sand), $\mathrm{pH}$ (water) of 6 and soil organic carbon of $1.2 \%$.

\section{Experimental design}

A long-term conservation agriculture (CA) experiment was initiated in 2004 to determine soil water and crop responses to tillage and maize residue mulching (Mupangwa, 2009). The experiment was set up as a split-plot Randomised Complete Block Design with three replications. Tillage system was the main plot $(63 \times 6 \mathrm{~m})$ factor and maize mulch rate the subplot $(8 \times 6 \mathrm{~m})$ factor. The crop sequence was a three-year maize-cowpea-sorghum rotation with only one crop present per season.

At the commencement of this study in 2008, hand-hoe weeding intensity (low and high) was added as a treatment factor. The weeding intensity treatments were superimposed on maize mulch rates of 0,4 and $8 \mathrm{tha}^{-1}$, with each mulch rate replicated twice per tillage main plot (conventional tillage compared against the minimum tillage (MT) systems of planting basin and ripper tine). The high weeding intensity treatment was carried out a week before planting, 1 week after planting (WAP), at 5 WAP and before harvesting. This weeding regime was maintained from the previous four seasons and represented the CA recommendation of frequent weeding (Mazvimavi and Twomlow, 2009). The low weeding intensity treatment, done only a week before planting and at 5 WAP, simulated the smallholder farmer practice of planting into a clean seedbed after early summer mouldboard ploughing and then hoe weeding 40 or more days after planting (Twomlow et al., 2006).

\section{Land preparation}

In order to keep CA fields weed-free during the dry season as recommended by the Zimbabwean CA Taskforce (Twomlow et al., 2008), weeds were removed using hoes in June 2008 in the 2008/09 season and in June, August and September 2009 in the $2009 / 10$ season. Although, most smallholder farmers do not traditionally hoe weed their fields in the dry season, the conventional (CONV) tillage plots in this study were also weeded at the same time as the MT plots. Under smallholder communal farming, free ranging livestock graze on weeds found in fields in the dry season such that the density of weeds and the seeds they set is likely to be lower than would be the case if weeds were left to grow and reproduce.

The MT systems were prepared on un-ploughed land in September of each year. Planting basins (PB) of $15 \mathrm{~cm} \times 15 \mathrm{~cm} \times$ $15 \mathrm{~cm}$ (length $x$ width $x$ depth) were dug using hand hoes at a row spacing of $90 \mathrm{~cm}$ with $60 \mathrm{~cm}$ between basins in a row. In the PB 
tillage system, only $11 \%$ of the total field surface areas were disturbed. In the ripper tine (RT) treatment, ripping was carried out using a commercially available ZimPlow ${ }^{\circledR}$ ripper tine attached to the beam of a donkey-drawn mouldboard plough. A depth of between 15 and $18 \mathrm{~cm}$ was achieved with rip lines spaced $90 \mathrm{~cm}$ apart. Of the total field surface area, $27 \%$ was disturbed in RT treatments. The positions of the basins and rip lines were maintained across the two seasons of this study, as had been done in the previous four seasons (Mupangwa, 2009). Conventional tillage was done each November on the first effective rains $(50 \mathrm{~mm})$ using a donkeydrawn ZimPlow ${ }^{\circledR}$ VS200 mouldboard plough and a ploughing depth of $15 \mathrm{~cm}$ was achieved.

\section{Crop management}

Cowpea (Vigna unguiculata L. cv. 86D719) was planted on the 26th of December, 2008. The cowpea was planted at a density of 74074 plants $\mathrm{ha}^{-1}$ in PB and RT treatments, as per the Zimbabwean CA Taskforce guidelines (Twomlow et al., 2008) to give a density of 74 074 plants $\mathrm{ha}^{-1}$. In CONV tillage, the recommended spacing of 60 $\mathrm{cm} \times 25 \mathrm{~cm}$ was used to give a density of 67667 plants ha ${ }^{-1}$. Neither basal nor top dress fertilizer was applied to the cowpea based on the fact that most smallholder farmers do not apply any fertilizer to cowpea (Ncube, 2007). Hand hoe weeding was done according to the weeding intensity treatment during the cropping season. The cowpea crop was harvested in April, 2009.

In the $2009 / 10$ season, cattle kraal manure $(17.5 \%$ organic carbon, $0.13 \% \mathrm{~N}, 0.11 \% \mathrm{P}$ ) was applied in October, 2009 at a rate of $3 \mathrm{t} \mathrm{ha}^{-1}$. Manure was spot applied into planting basins and banded along the rip lines. In CONV tillage plots, manure was banded along the planting furrows after ploughing. To check the manure for contamination with weed seeds, samples of the manure were assessed for the presence of weed seeds using the seedling emergence method of Rupende et al. (1998). Unlike observations made on manure from the smallholder sector (Rupende et al., 1998), no weed seedlings emerged in the eight months the manure was kept in the greenhouse. This suggests that the manure from the commercial herd at Matopos Research Station was free of viable weed seeds. Sorghum (Sorghum bicolor L. cv. Macia) was planted on the 2nd of December, 2009. In PB and RT plots, planting was done according to the CA guidelines (Twomlow et al., 2008) to give a sorghum population of 74074 plants $^{-1} \mathrm{~h}^{-1}$ in both tillage systems. In CONV tillage the recommended spacing of 75 $\mathrm{cm} \times 20 \mathrm{~cm}$ was used to give a population of 88889 plants ha ${ }^{-1}$. During the cropping season, hoe weeding was done according to the weeding intensity treatments. Ammonium nitrate $(34.5 \% \mathrm{~N})$ was applied to the sorghum crop at a rate of $20 \mathrm{~kg} \mathrm{~N} \mathrm{ha}^{-1}$ as topdressing at 5 WAP. The sorghum crop was harvested in April, 2010.

\section{Data collection}

Weeds were sampled at $1,4,9$ and 13 WAP from a $0.5 \mathrm{~m}^{2}$ quadrat thrown twice at random positions into each sub-plot. Weeds were identified to species level following Makanganise and Mabasa (1999) and counted. Stem counts replaced plant counts for perennial monocots. A number of grasses (Setaria incrassata (Hochst.) Hack; Setaria pumila (Poir.) Roem. and Schult; Setaria verticillata (L.) Beauv., and Aristidia aspera) was classified as Setaria spp due to difficulties in identifying them at the seedling stage.

\section{Statistical analysis}

Prior to analysis, weed density data was square root transformed ( $x$
+ 0.5) to homogenize variances (Gomez and Gomez, 1984). Weed diversity was measured using weed species richness (number of species) and the Shannon-Weiner diversity and evenness indices. Shannon-Weiner' diversity index $\mathrm{H}$ ' was calculated for each sub-plot after Magurran (1988) as follows:

$\mathrm{H}^{\prime}=(N \ln N-\operatorname{Sum}(n \ln n)) / N$

Where $H^{\prime}$ measures species diversity through proportional abundance of species, with a higher value signifying greater diversity, $N$ is the total population density $\mathrm{m}^{-2}$ and $n$ is the population of each weed species found in this area; and evenness index $\mathrm{E}$ :

$\mathrm{E}=\mathrm{H}^{\prime} / \ln N$

Where $E$ is the relationship between the observed number of species and total number of species, with a greater value indicating greater uniformity between species abundances.

The analysis of the weed density and diversity data was performed separately for each season (crop). The data were subjected to the analysis of variance using GenStat Release 9.1 (Lawes Agricultural Trust 2006). The treatment and interaction standard error of differences (SED) of the means from split-plot ANOVA were used to separate treatment means at $5 \%$ level of significance.

\section{RESULTS AND DISCUSSION}

\section{Seasonal rainfall}

Although the 2008/09 cropping season received $11 \%$ more rainfall between November and March (day 0 to 150 ) than the $2009 / 10$ season, the rains were poorly distributed (Figure 1). The month of December 2008 was characterized by low rainfall which fell towards the end of the month resulting in the cowpea crop being planted late. In contrast, January 2009 was very wet, receiving almost half of the total rainfall of the 2008/09 season (Figure 1A). The incessant rains in January 2009 resulted in poor weed control such that hoe weeding had to be repeated (weeding $3 a$ and $3 b$ ) within the same month to reduce weed infestations in all treatments. In the 2009/10 season, the high rains received in December 2009 enabled sorghum to be planted early. There was a more even rainfall distribution in this season compared to the 2008/09 season (Figure 1).

\section{General effects on weed species and density}

The weed species identified and the significant treatment effects of tillage, maize mulch rate and weeding intensity on individual weed species density and community diversity in cowpea and sorghum crops are summarized in Tables 1 to 5 . There was no significant $(P<0.05)$ tillage $x$ maize mulch rate $x$ weeding intensity interaction on weed composition in both crops. The tillage $x$ maize mulch rate interaction was significant $(P<0.05)$ for the density of Leucas martinicensis, Setaria spp and Urochloa panicoides in cowpeas during the 2008/09 


\section{A. $2008 / 09$}

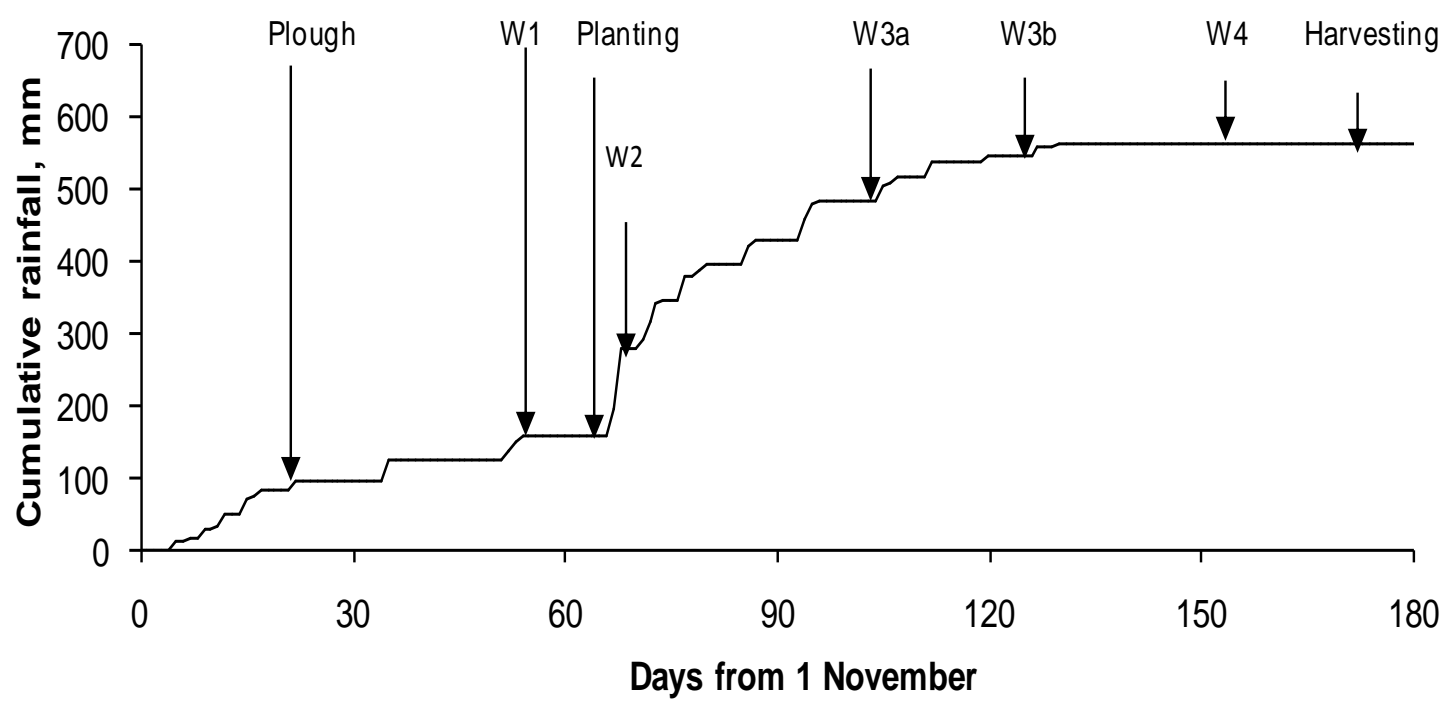

B. $2009 / 10$

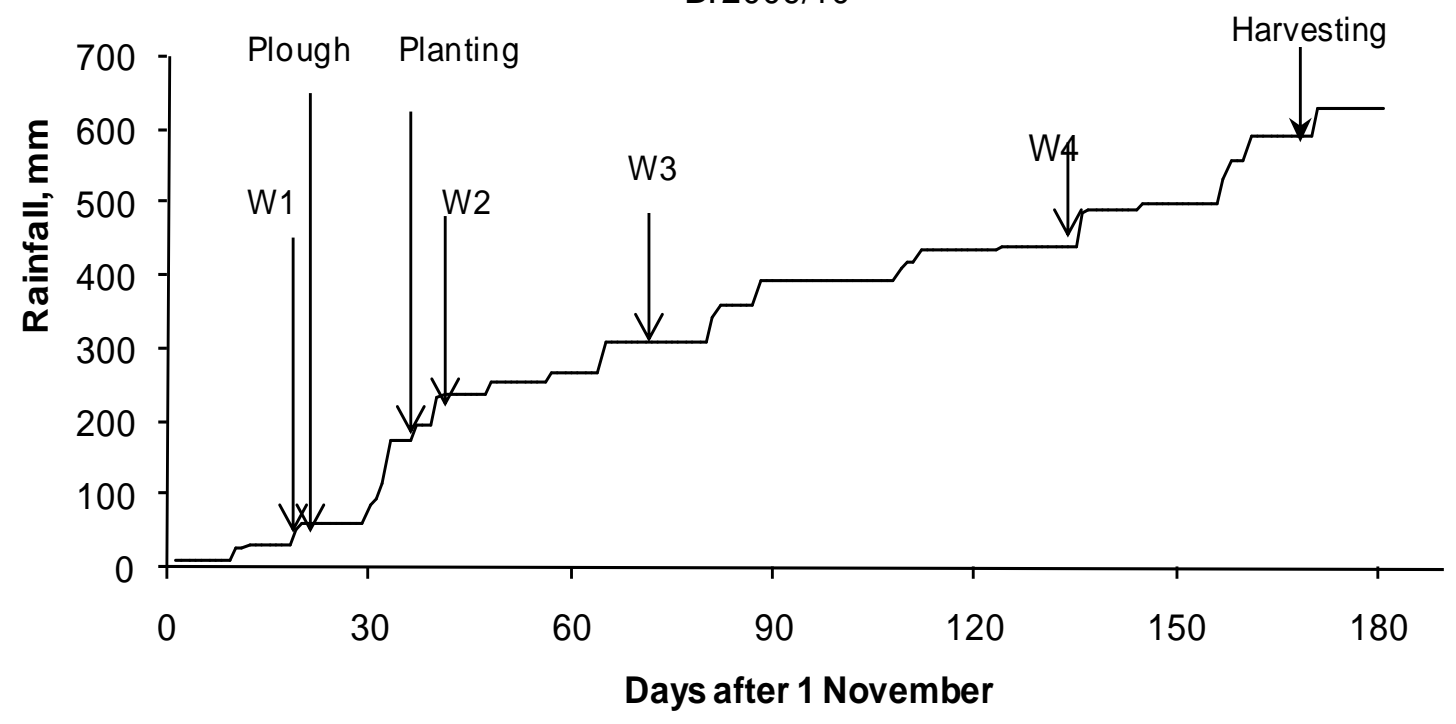

Figure 1. Cumulative daily rainfall received and the timing of crop management practices at Matopos Research station during the A. 2008/09 (561.1 mm) and B. 2009/10 (590.5 mm) cropping seasons. W1, W2, W3 and W4: high intensity hoe weeding operations; W1 and W3: low intensity hoe weeding operations.

season and Boerhavia diffusa and Schkuria pinnata in sorghum during the 2009/10 season (Figure 2). There was a significant $(P<0.05)$ tillage $x$ weeding intensity interaction on the density of Argemone mexicana, Cleome monophylla and Malva verticillata in cowpeas during 2008/09 season and A. mexicana, Bidens pilosa and $U$. panicoides in sorghum during the $2009 / 10$ season (Figure 3 ). The maize mulch rate $x$ weeding intensity interaction was significant $(P<0.05)$ for the density of Ipomea plebia, S. pinnata and Setaria spp (Figure 4) and annual monocots (Figure 5) in sorghum grown during the 2009/10 season. These interactions are discussed below in detail under the respective subtitles.

\section{Specific weed densities}

Twenty-six weed species were identified in the cowpea phase in the first 13 weeks after planting (Table 1). Of these, twenty-four were also found among the twenty-five 
Table 1. Mean density of weed species (no. $\mathrm{m}^{-2}$ ) found in the first 13 weeks in cowpea and sorghum crops grown at Matopos Research Station during the 2008/09 and 2009/10 seasons, respectively.

\begin{tabular}{|c|c|c|c|}
\hline \multirow{2}{*}{ Life cycle } & \multirow{2}{*}{ Latin binomial } & \multicolumn{2}{|c|}{ Mean density $\mathrm{m}^{-2}(\mathrm{~N}=54)$} \\
\hline & & Cowpea (2008/09) & Sorghum $(2009 / 10)$ \\
\hline \multicolumn{2}{|c|}{ Annual dicots } & 87.3 & 123.7 \\
\hline & Acalypha crenata Hochst. Ex. A. Rich. & 2.4 & 1.8 \\
\hline & Acanthospermum hispidum DC. & 0.1 & 0.02 \\
\hline & Alternanthera repens (Linnaens) Link & 10.9 & 15.9 \\
\hline & Amaranthus hybrius $\mathrm{L}$. & 0.7 & 0.8 \\
\hline & Argemone mexicana $\mathrm{L}$. & 2.0 & 0.2 \\
\hline & Bidens pilosa $L$. & 1.2 & 7.3 \\
\hline & Cleome monophylla $\mathrm{L}$. & 0.4 & 0.1 \\
\hline & Conyza albida (Retz.) E.H. Walker & 2.9 & 0.4 \\
\hline & Corchorus tridens $\mathrm{L}$. & 10.0 & 11.1 \\
\hline & Datura stramonium L. & 0.1 & 0.4 \\
\hline & Euphorbia prostrata & 0.2 & 17.8 \\
\hline & Gnaphalium pensy/vanicum Willd & 6.3 & - \\
\hline & Ipomea plebia L. & 0.04 & 0.2 \\
\hline & Leucas martinicensis (Jacq.)R.Br. & 42.4 & 53.9 \\
\hline & Malva verticillata $\mathrm{L}$. & 0.1 & - \\
\hline & Portulaca oleracea L. & 3.1 & 8.2 \\
\hline & Schkuria pinnata (lam.) Thell. & 2.1 & 1.6 \\
\hline & Sonchus oleraceus L. & 1.1 & 3.4 \\
\hline & Tagetes minuta L. & 1.2 & 3.4 \\
\hline \multicolumn{2}{|c|}{ Annual monocots } & 101.7 & 139.9 \\
\hline & Commelina benghalensis $L$ & 13.9 & 18.5 \\
\hline & Eleusine indica (L.) Gaertn. & 4.3 & 3.5 \\
\hline & Setaria spp & 87.7 & 110.5 \\
\hline & Urochloa panicoides Beauv & 0.8 & 7.4 \\
\hline \multicolumn{2}{|c|}{ Perennial dicot } & 3.6 & 3.7 \\
\hline & Boerhavia diffusa L & 3.6 & 2.6 \\
\hline & Sida alba L. & - & 1.1 \\
\hline \multicolumn{2}{|c|}{ Perennial monocot } & 2.2 & 7.0 \\
\hline & Cynodon dactylon (L.) Pers. & 1.8 & 1.3 \\
\hline & Cyperus esculentus $\mathrm{L}$. & 0.4 & 0.1 \\
\hline & Total & 194.8 & 274.3 \\
\hline
\end{tabular}

weed species identified in the sorghum phase the following season. Of the 27 weed species identified during the two years of the study, all the monocot weed species were present in both seasons. However, the perennial dicot Sida alba was absent in the 2008/09 season and the annual dicots Gnaphalium pensylvanicum and Malve verticillata were absent in the $2009 / 10$ season. The density of most weed species varied with season probably reflecting the differences between the two seasons in terms of precipitation (Figure 1) and the conditions required by the different weed species for growth under the different stages of the rotation.
Annual weed species made up over $95 \%$ of the weed community with annual monocots being the most abundant weed group in both crops (Table 1). The dominant weed species in the two crops were Setaria spp, L. martinicensis and C. benghalensis. However, in sorghum these species only comprised $67 \%$ of the weed community compared to $71 \%$ in cowpeas. The weed $E$. prostrata that was a minor weed in cowpea $(0.1 \%$ of community) increased in density in sorghum $(6.5 \%$ of community) to become the fourth most abundant weed in the community. In addition, weed density $\left(\mathrm{m}^{-2}\right)$ under sorghum was $41 \%$ higher than under cowpea. 
Table 2. Effect of tillage on density of weed species ${ }^{a}$ found in cowpea (2008/09 season) and sorghum (2009/10 season) at Matopos Research Station.

\begin{tabular}{|c|c|c|c|c|c|c|c|c|}
\hline \multirow{4}{*}{ Weed species } & \multicolumn{8}{|c|}{ Weed density $\left(\mathrm{m}^{-2}\right)$} \\
\hline & \multicolumn{4}{|c|}{ Cowpea } & \multicolumn{4}{|c|}{ Sorghum } \\
\hline & \multicolumn{4}{|c|}{ Tillage system ( $N=18)$} & \multicolumn{4}{|c|}{ Tillage system $(\mathrm{N}=18)$} \\
\hline & CONV & RT & PB & SED & CONV & RT & PB & SED \\
\hline A. crenata & 2.1 & 1.0 & 1.2 & 0.27 & 1.8 & 1.1 & 1.0 & NS \\
\hline C. tridens & 4.0 & 2.4 & 2.3 & 0.30 & 3.8 & 3.0 & 2.9 & NS \\
\hline P. oleracea & 1.4 & 2.0 & 1.9 & 0.15 & 2.8 & 2.6 & 2.6 & NS \\
\hline S. pinnata & 1.0 & 1.4 & 1.4 & NS & 0.8 & 1.3 & 1.4 & 0.16 \\
\hline S. alba & - & - & - & & 1.5 & 1.0 & 0.8 & 0.14 \\
\hline Total density & 14.5 & 13.7 & 13.3 & NS & 14.8 & 17.0 & 15.9 & NS \\
\hline
\end{tabular}

${ }^{a}$ weed species that had a significant response to treatment in at least one crop; CONV: Conventional mouldboard plough, RT: ripper tine, PB: Planting basin; SED, standard error of the difference between mean values; NS, not significantly different $(P>0.05)$; Square root $(x+0.5)$ transformed data presented with value of $0.7=0$ untransformed data.

Table 3. Effect of maize mulch rate on density of weed species ${ }^{a}$ found in cowpea (2008/09 season) and sorghum (2009/10 season) at Matopos Research Station.

\begin{tabular}{|c|c|c|c|c|c|c|c|c|}
\hline \multirow{4}{*}{ Weed species } & \multicolumn{8}{|c|}{ Weed density $\left(\mathrm{m}^{-2}\right)$} \\
\hline & \multicolumn{4}{|c|}{ Cowpea } & \multicolumn{4}{|c|}{ Sorghum } \\
\hline & \multicolumn{4}{|c|}{ Mulch rate t ha ${ }^{-1}(\mathrm{~N}=18)$} & \multicolumn{4}{|c|}{ Mulch rate t ha ${ }^{-1}(\mathrm{~N}=18)$} \\
\hline & 0 & 4 & 8 & SED & 0 & 4 & 8 & SED \\
\hline G. pensylvanicum & 1.8 & 2.7 & 2.7 & 0.23 & - & - & - & \\
\hline C. albida & 1.2 & 1.7 & 2.1 & 0.26 & 0.9 & 0.8 & 0.9 & NS \\
\hline C. tridens & 3.5 & 3.0 & 2.8 & NS & 3.9 & 3.2 & 2.7 & 0.32 \\
\hline B. diffusa & 2.2 & 1.6 & 1.7 & NS & 1.7 & 1.3 & 1.7 & 0.18 \\
\hline E. indica & 1.4 & 2.3 & 2.3 & 0.32 & 1.6 & 1.7 & 1.9 & NS \\
\hline E. prostrata & 0.8 & 0.8 & 0.7 & NS & 4.8 & 3.6 & 2.9 & 0.46 \\
\hline L. martinicensis & 5.4 & 7.3 & 5.3 & 0.63 & 4.8 & 8.0 & 6.5 & 0.90 \\
\hline P. oleracea & 1.9 & 1.7 & 1.6 & NS & 2.9 & 3.0 & 2.2 & 0.29 \\
\hline S. pinnata & 0.9 & 1.1 & 1.8 & 0.29 & 0.7 & 1.0 & 1.8 & 0.15 \\
\hline Setaria spp & 8.6 & 9.1 & 9.0 & NS & 9.3 & 11.1 & 8.8 & 0.59 \\
\hline Annual dicot & 8.3 & 10.1 & 9.0 & 0.57 & 10.5 & 11.5 & 10.2 & NS \\
\hline Annual monocot & 9.4 & 10.2 & 10.1 & NS & 10.5 & 12.3 & 10.5 & 0.69 \\
\hline Perennial dicot & 2.2 & 1.6 & 1.7 & NS & 2.0 & 1.6 & 1.9 & NS \\
\hline Perennial monocot & 1.4 & 1.0 & 1.0 & NS & 2.1 & 0.9 & 1.8 & NS \\
\hline Total & 13.0 & 14.6 & 13.9 & 0.39 & 15.7 & 17.0 & 15.0 & 0.66 \\
\hline
\end{tabular}

The majority of annual weed seeds requires light for germination and may have benefited from increased light penetration under the more open sorghum canopy. Sorghum is reported to grow slowly early in the cropping season with maximum growth occurring before or after anthesis (Traor'e et al., 2003), which occurred nine weeks after planting for the sorghum crop in this experiment. In contrast, the semi-erect cowpea varietyused in this study was observed to grow fast and cover the ground earlier than sorghum. The fast canopy development in cowpea probably resulted soil shading and suppression of weed germination. Based on these observations, the use of competitive crops or cultivars is one of the strategies that can be used by resource-poor farmers to suppress growth of annual weed species early in the cropping season.

\section{Tillage effect}

Tillage had no significant $(P>0.05)$ effect on the total 
Table 4. Effect of intensity of hand-hoe weeding on density of weed species ${ }^{a}$ found in cowpea (2008/09 season) and sorghum (2009/10 season) crops at Matopos Research Station.

\begin{tabular}{|c|c|c|c|c|c|c|}
\hline \multirow{4}{*}{ Weed species } & \multicolumn{6}{|c|}{ Weed density $\left(\mathrm{m}^{-2}\right)$} \\
\hline & & Npea & & & rghum & \\
\hline & \multicolumn{3}{|c|}{ Weeding intensity $(\mathrm{N}=27)$} & \multicolumn{3}{|c|}{ Weeding intensity $(\mathrm{N}=27)$} \\
\hline & Low & High & SED & Low & High & SED \\
\hline S. oleraceus & 1.2 & 0.9 & 0.09 & 1.0 & 0.9 & NS \\
\hline A. repens & 2.6 & 2.6 & NS & 4.2 & 2.8 & 0.47 \\
\hline A. mexicana & 1.2 & 1.2 & NS & 0.9 & 0.7 & 0.05 \\
\hline B. pilosa & 1.1 & 1.1 & NS & 2.6 & 1.7 & 0.27 \\
\hline C. benghalensis & 3.2 & 2.6 & NS & 4.9 & 2.8 & 0.38 \\
\hline E. indica & 1.5 & 1.2 & NS & 2.1 & 1.4 & 0.28 \\
\hline L. martinicensis & 5.0 & 4.8 & NS & 8.3 & 4.6 & 0.62 \\
\hline S. pinnata & 1.2 & 1.2 & NS & 1.4 & 1.0 & 0.14 \\
\hline Setaria spp & 8.7 & 8.3 & NS & 12.4 & 7.0 & 0.56 \\
\hline U. panicoides & 0.9 & 0.8 & NS & 2.9 & 2.0 & 0.30 \\
\hline Annual dicot & 9.4 & 8.9 & NS & 12.8 & 8.7 & 0.47 \\
\hline Annual monocot & 10.2 & 9.6 & NS & 14.1 & 8.1 & 0.69 \\
\hline Perennial dicot & 1.8 & 1.8 & NS & 1.5 & 1.6 & NS \\
\hline Perennial monocot & 1.0 & 1.2 & NS & 1.8 & 1.4 & NS \\
\hline Total & 14.2 & 13.5 & NS & 19.4 & 12.4 & 0.59 \\
\hline
\end{tabular}

${ }^{a}$ weed species that had a significant response to treatment in at least one crop; SED, standard error of the difference between mean values; NS, not significantly different $(P>0.05)$; Square root $(x+0.5)$ transformed data presented with value of $0.7=0$ untransformed data.

Table 5. Richness (number of species per plot), diversity (Shannon's $H$ ' index) and evenness (Shannon's E index) for weed species present under different treatments in cowpea (2008/09 season) and sorghum (2009/10 season) crops grown at Matopos Research Station.

\begin{tabular}{|c|c|c|c|c|c|c|}
\hline \multirow{2}{*}{ Treatment } & \multicolumn{3}{|c|}{ Cowpea weed diversity indices } & \multicolumn{3}{|c|}{ Sorghum weed diversity indices } \\
\hline & Richness & Diversity & Evenness & Richness & Diversity & Evenness \\
\hline \multicolumn{7}{|l|}{ Tillage } \\
\hline CONV & 11.4 & 1.48 & 0.61 & 13.2 & 1.73 & 0.68 \\
\hline RT & 12.1 & 1.63 & 0.66 & 13.2 & 1.78 & 0.68 \\
\hline PB & 11.6 & 1.63 & 0.67 & 12.4 & 1.73 & 0.71 \\
\hline P-value & 0.793 & 0.214 & 0.277 & 0.617 & 0.863 & 0.738 \\
\hline SED & NS & NS & NS & NS & NS & NS \\
\hline \multicolumn{7}{|l|}{ Mulch t ha ${ }^{-1}$} \\
\hline 0 & 11.1 & 1.55 & 0.65 & 12.9 & 1.81 & 0.71 \\
\hline 4 & 12.2 & 1.56 & 0.63 & 12.2 & 1.61 & 0.65 \\
\hline 8 & 11.9 & 1.62 & 0.66 & 13.1 & 1.83 & 0.70 \\
\hline P-value & 0.201 & 0.595 & 0.534 & 0.099 & 0.024 & 0.062 \\
\hline SED & NS & NS & NS & NS & 0.077 & NS \\
\hline \multicolumn{7}{|c|}{ Weeding intensity } \\
\hline Low & 12 & 1.6 & 0.65 & 13.6 & 1.7 & 0.65 \\
\hline High & 11.5 & 1.56 & 0.64 & 12.2 & 1.8 & 0.72 \\
\hline P-value & 0.376 & 0.586 & 0.823 & 0.02 & 0.052 & 0.001 \\
\hline SED & NS & NS & NS & 0.55 & NS & 0.017 \\
\hline
\end{tabular}

CONV: Conventional mouldboard plough, RT: ripper tine, PB: Planting basin; SED, standard error of the difference between mean values; NS, not significantly different $(P>0.05)$. 


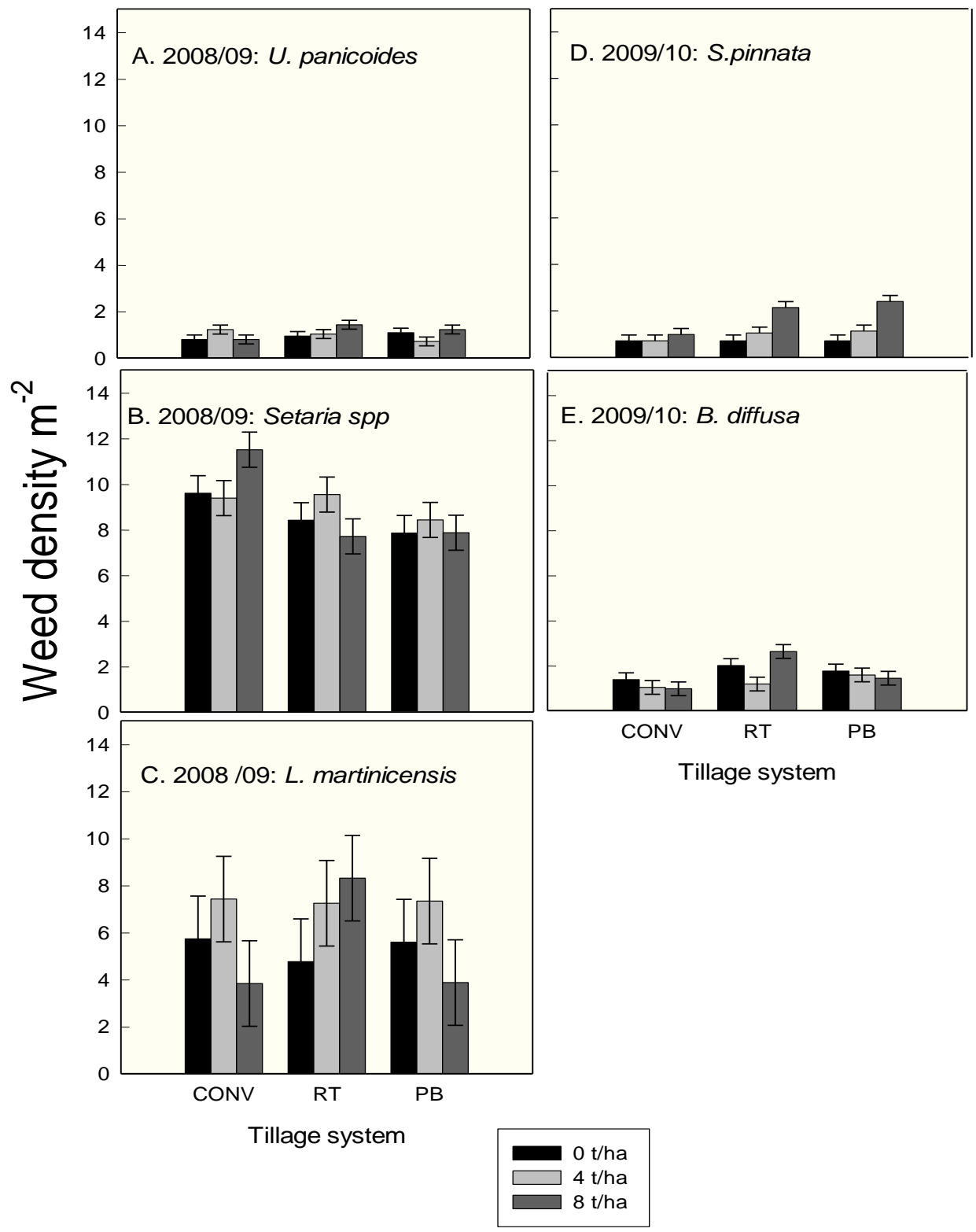

Figure 2. Tillage $x$ maize mulch rate interaction on total density of A. U. panicoides, B. Setaria spp and C. L. martinicensis in cowpea (2008/09) and D. S. pinnata and E. B. diffusa in sorghum (2009/10) grown at Matopos Research Station. Bars represent \pm SED.

weed density in both cowpea and sorghum crops (Table 2). Conventional tillage was associated with significantly $(\mathrm{P}<0.05)$ greater densities of $A$. crenata and $C$. tridens than the MT systems in cowpea. Although not statistically significant, a similar trend was observed for the two weed species in sorghum. The density of $S$. alba was significantly $(P<0.05)$ higher in CONV tillage than in MT systems in sorghum (Table 2). The weed $C$. tridens is characterized by a high degree of dormancy with germination increasing with seed coat scarification (Dzerefos et al., 1994). Weed species such as $C$. tridens that require burial in order to germinate may, therefore, be favoured in CONV tillage and decline in MT systems where there is no soil inversion. Such species survive soil burial by undergoing dormancy which is broken when the seeds encounter suitable conditions when they are brought to the soil surface through subsequent ploughing events.

A significantly $(\mathrm{P}<0.05)$ higher density of $P$. oleracea was found under MT systems than CONV tillage in cowpea (Table 2). A similar significant $(P<0.05)$ trend was observed for $S$. pinnata in sorghum where weed density was $38 \%$ higher under MT systems than CONV tillage. The weed species $P$. oleracea is small seeded 


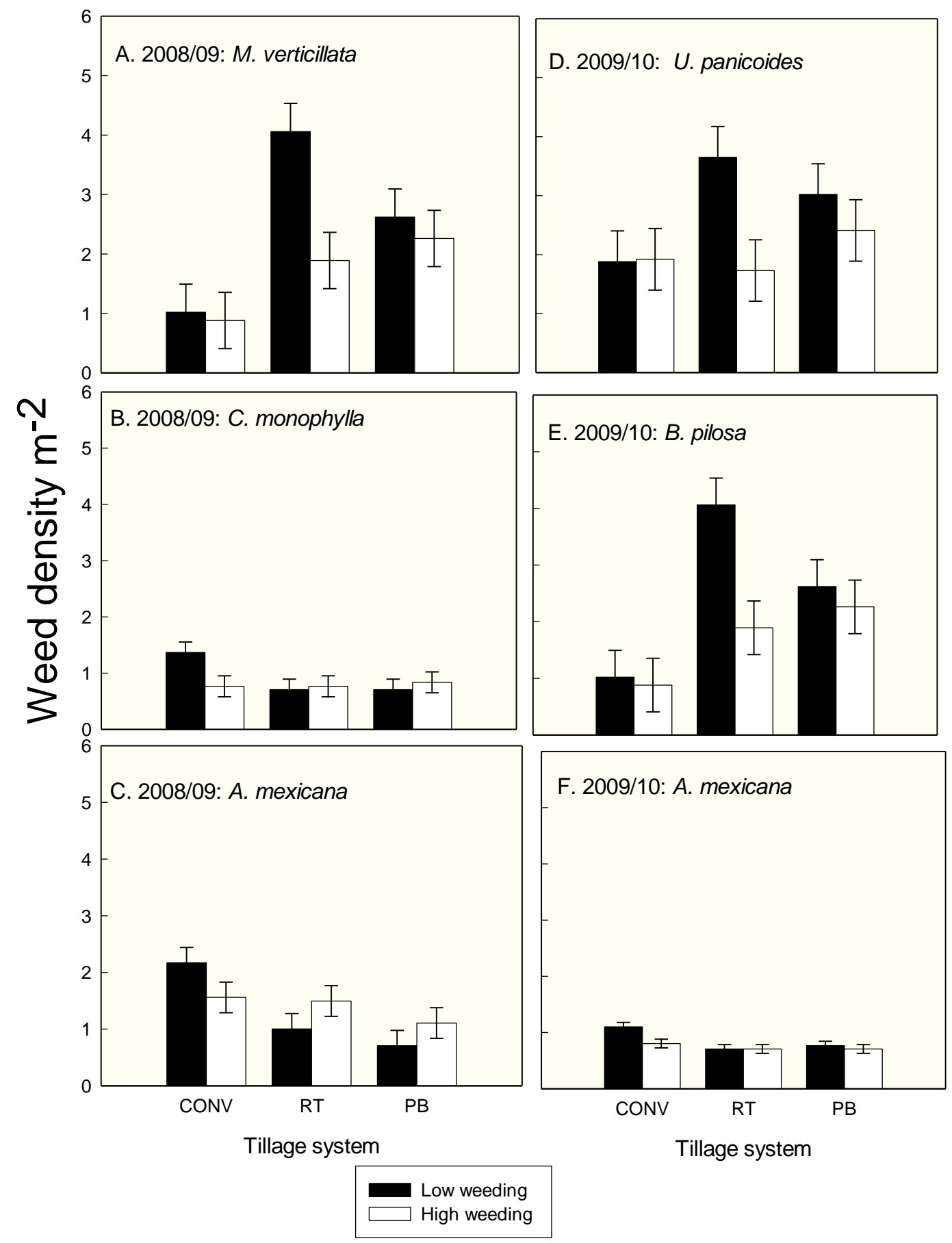

Figure 3. Tillage $x$ weeding intensity interaction on total density of A. M. verticillata, B. C. monophylla and C. A. Mexicana in cowpea (2008/09) grown and D. U. panacoides, E. B. pilosa and F. A. mexicana in sorghum (2009/10) grown at Matopos Research Station. Bars represent \pm SED.

(Makanganise and Mabasa, 1999) and is likely to be more sensitive to light than large seeded weeds (Chauhan et al., 2006) such as C. tridens. Small seeded weed species may, therefore, benefit from the low seed burial and exposure of seed to light under MT systems. Chauhan and Johnson (2009) also observed that $P$. oleracea emergence was greater under zero till than under conventional tillage. The ability of $P$. oleracea to survive for some time after being uprooted then setting root and producing new plants under moist conditions makes it difficult to eradicate by cultivation. This species, therefore, has the potential to become a serious weed in 


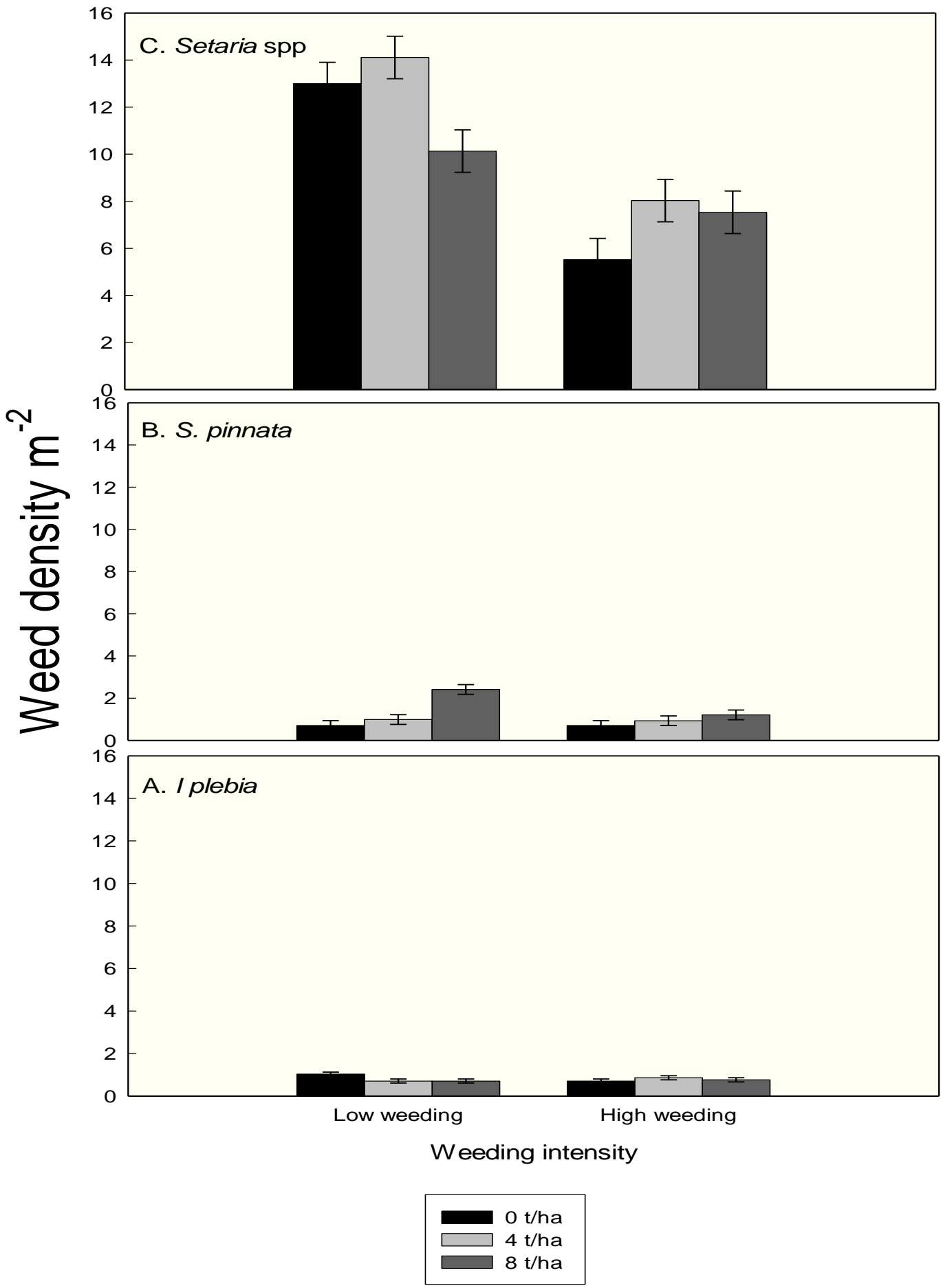

Figure 4. Maize mulch rate $x$ weeding intensity interaction on total density of A. I. plebia, B. S. pinnata and $C$. Setaria spp in sorghum grown at Matopos Research Station. Bars represent \pm SED.

MT systems especially for resource-poor farmers without access to pre-emergence herbicides.

\section{Maize mulch effect}

Mulching was generally associated with an increase
$(\mathrm{P}<0.05)$ in weed density compared to the un-mulched treatment in both the cowpea and sorghum crops. Retaining maize residue as surface mulch significantly $(P<0.05)$ increased the density of $C$. albida, E. indica, $G$. pensylvanicum, L. martinicensis and $S$. pinnata under cowpea and L. martinicensis, S. pinnata and Setaria spp 


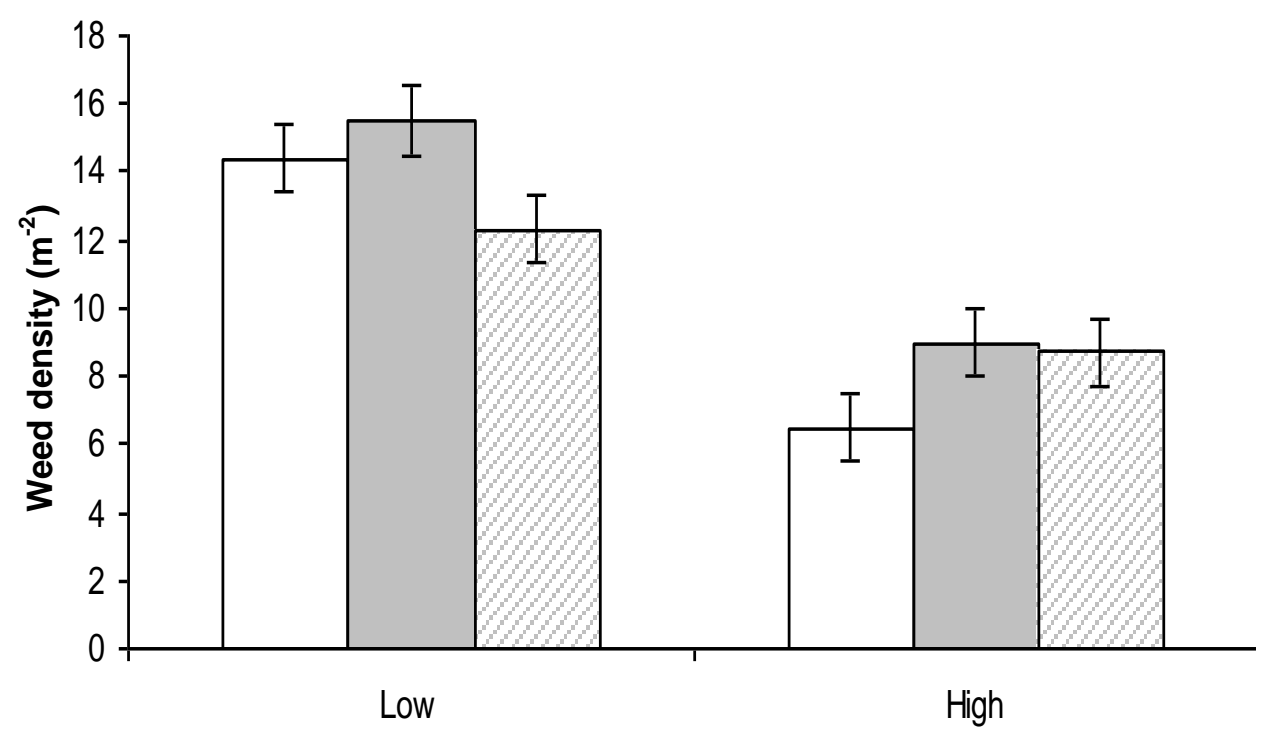

\section{Weeding intensity}

$\square 0$ tha $\square 4$ tha $\square 8$ tha

Figure 5. Maize mulch rate $x$ weeding intensity interaction on total density of annual monocot species found in sorghum grown during the 2009/10 season at Matopos Research Station. Bars represent \pm SED.

under sorghum (Table 3) in this study. The changes in soil temperature, moisture, light availability and soil nitrate levels on crop residue mulching (Christofolleti et al., 2007) probably created conditions favourable for the germination of some weed species. If the maize mulch resulted in moisture conservation as was previously reported by Mupangwa (2009) at the same site, this may have increased the germination and growth of species such $C$. albida and G. pensylvanicum that are commonly found in damp places. In addition, the maize residue may have trapped seeds of wind-dispersed weed species such as $C$. albida and $L$. martinicensis which later germinated and increased the density of these weed species under the mulch treatment.

For some weed species, the increase in density on mulch retention was specific to a tillage system. Of interest was the significant $(P<0.05)$ increase in weed density observed on mulching in MT systems for $L$. martinicensis, Setaria spp and $U$. panicoides in the cowpea phase of the rotation and for $S$. pinnata and $B$. diffusa in the sorghum phase (Figure 2). The association of $S$. pinnata with MT systems (Table 2) and mulching suggests that this weed is likely to be found in greater densities under CA than CONV tillage. However, the weed is easily controlled by mechanical methods including hoe weeding and is, thus, unlikely to emerge as a problem weed in CA.

The intermediate maize mulch rate of $4 \mathrm{t} \mathrm{ha}^{-1}$ had the highest density $(\mathrm{P}<0.05)$ of $L$. martinicensis, and increased annual dicot weed density by $18 \%$ and total weed density by $11 \%(\mathrm{P}<0.01)$ compared to the unmulched treatment in the cowpea crop. A similar significant $(P<0.05)$ trend was observed in the sorghum crop for $P$. oleraceae, Setaria spp and L. martinicensis with increases in annual monocots (15\%) and total weed density $(8 \%)$ at $4 \mathrm{t} \mathrm{ha}^{-1}$ maize mulch rate relative to where no mulch was retained (Table 3 ). In most cases, a lower weed density was observed under the maize mulch rate of $8 \mathrm{tha}^{-1}$ than the $4 \mathrm{tha}^{-1}$ maize mulch rate. This may have been due to a reduction in seed germination due to increased shading of the soil under the thicker layer of mulch at $8 \mathrm{tha}^{-1}$.

The presence of maize residue at rates of 4 and $8 \mathrm{tha}^{-1}$ on the soil surface was also associated with weed suppression in some species. Reduced weed density on mulching was observed only in sorghum where significant $(P<0.05)$ suppression was observed across all tillage systems in the densities of $C$. tridens, $P$. oleracea and $E$. prostrata (Table 3 ) and under ripper tine for $B$. diffusa (Figure 3). Chauhan and Johnson (2009) also observed that $P$. oleracea seedling emergence declined exponentially with increased rates of rice residue. Crop residue mulch has been reported to reduce light transmittance and daily soil temperature amplitude which can lead to weed seed germination reduction or inhibition (Christofolleti et al., 2007).This may be the reason for the lower weed density of some species under the maize mulch in the sorghum crop. In addition, for small seeded 
weed species like $P$. oleracea the maize mulch may have acted as a physical barrier to weed seedling emergence and growth. For $C$.tridens and $P$. oleracea a significant reduction in density was observed only at a maize mulch rate of $8 \mathrm{t} \mathrm{ha}^{-1}$. However, smallholder farmers in semi-arid areas are unlikely to retain even the lower maize reside rate $\left(4 \mathrm{tha}^{-1}\right)$ due to the current low cereal residue yields and their important use as livestock feed in mixed croplivestock systems.

In this study, the effect of the maize mulch on weed density varied with species, crop grown (Table 3 ) and for some species with tillage system (Figure 2) which makes it impossible to make generic conclusions. According to Farooq et al. (2011), generalised statements about CA are often inappropriate because the effect of CA components is in most cases site specific with interactions between CA components common. Weed suppression on maize residue mulching was observed for some weed species, but not all, and only under the sorghum phase of the rotation. For species such as $P$. oleracea that had high densities under MT systems (Table 2), mulching as is being promoted under CA can be a weed control strategy. However, retaining $4 \mathrm{tha}^{-1}$ or more of maize residue for suppression of four out of twenty five weed species with no overall decrease in weed density is unlikely to be a practice that is adopted by smallholder farmers. Maize mulching was, however, observed to increase the density of problematic weeds species such as $E$. indica in the cowpea phase of the rotation (Table 3) which is reported to be the most aggressive weed in Zimbabwe (Makanganise and Mabasa, 1999). The marked increase in total weed density in general and of specific problem weeds especially at the maize mulch rate of $4 \mathrm{t} \mathrm{ha}^{-1}$ is likely to exacerbate smallholder farmers' weed management problems. In fact, maize mulching was associated with decreased sorghum grain yield in the 2009/10 cropping season probably as a result of high weed growth under mulch (Mashingaidze et al., 2012).

\section{Intensity of hoe weeding effect}

The high weeding intensity significantly $(P<0.001)$ reduced total weed density, the density of annual dicots by $31 \%$ and annual monocots by $43 \%$ in the sorghum crop (Table 4).

The higher density of annual weeds observed in the low weeding intensity treatment in sorghum may be due to the fact that a greater seed returns to the soil seed bank under cowpea.

During the cowpea phase of the rotation, the shorter weeding period in the low weeding intensity probably allowed most of the late season annual weeds to produce seed and add to the soil reservoir.

Doubling the number of hoe weeding operations within the cropping season significantly $(\mathrm{P}<0.05)$ decreased the density of $S$. oleraceus in the cowpea crop and of $A$. repens, A. mexicana, B. pilosa, C. benghalensis. E. indica, L. martinicensis, S. pinnata, Setaria spp and $U$. panicoides in the sorghum phase of the rotation (Table 4). However for some species in both crops, the effect of weeding intensity was confounded within the significant $(P<0.05)$ tillage* weeding intensity interaction (Figure 3 ).

The density of $C$. monophylla in the cowpea crop and A. mexicana in both crops was reduced in the high weeding treatment than in low weeding intensity only under CONV tillage (Figure 3B, C and F). On the other hand, the high weeding intensity treatment in the RT system reduced the density of $M$. verticillata in cowpea crop and of $U$. panicoides and $B$. pilosa in the sorghum crop compared to the low weeding intensity treatment (Figure $3 \mathrm{~A}, \mathrm{D}$ and $\mathrm{E}$ ).

In addition, the effect of the intensity of hoe weeding was confounded within the significant $(\mathrm{P}<0.05)$ maize mulch rate * weeding intensity for $I$. plebia, $S$. pinnata and Setaria spp in the sorghum crop (Figure 4). The density of $I$. plebia was reduced on mulching only in the low weeding treatment (Figure 4A). The significant $(P<0.01)$ interaction for $S$. pinnata showed that the high weed density at $8 \mathrm{t} \mathrm{ha}^{-1}$ (Table 3) was found only under the low weeding intensity treatment (Figure 4B). On the other hand, the high Setaria spp density on maize mulching in sorghum (Table 3) was found under the high weeding intensity treatment (Figure 4C).

In contrast, under the low weeding intensity treatment, there was significant suppression of Setaria spp at the maize mulch rate of $8 \mathrm{tha}^{-1}$. A similar trend was observed for the annual monocots in the sorghum crop (Figure 5) which was not surprising as Setaria spp was the dominant weed in this group comprising $90 \%$ by density. The results from the annual monocots and I. plebia suggest that mulching may be a useful strategy for reducing the density of these weeds species under low weed management conditions.

In agreement with the findings of Gianessi (2009), timely and frequent weeding reduced weed infestations in all tillage practices in this study. The stronger responses of weed species density to weeding intensity and maize mulching than to tillage system suggests that these had a stronger effect on weed seed germination and emergence than tillage. Booth and Swanton (2002) also noted that weed management methods such as herbicide application are a stronger constraint to community assembly than tillage intensity. Based on the findings of this study frequent and timely hoe weeding was effective in reducing weed density and should, therefore, be encouraged in MT systems of resource-poor smallholder farmers until alternative weed management regimes such as herbicides become possible. However, it is worth noting that the requirement for a high weeding frequency in CA as observed in this study has been cited by smallholder farmers in southern Africa as the main constraint to expansion of the area under CA-based tillage systems (Baudron et al., 2007). 


\section{Weed community diversity}

Tillage had no significant effect on species richness, Shannon' diversity $(\mathrm{H})$ and evenness $(\mathrm{E})$ indices in both the cowpea and sorghum phases of the rotation (Table 5 ); these results are consistent with the findings of Legere et al. (2005). This lack of an increase in weed diversity with reduction in soil disturbance can be attributed to the confounding effect of other agronomic and environmental factors. Weed diversity indices in this study were low $\left(\mathrm{H}^{\prime}<2.0\right)$ and similar to indices recorded in maize fields in eastern Zimbabwe by MandunaMadamombe et al. (2008). The evenness index values suggest little evidence of dominant weed species in any of the tillage systems.

Although, there were changes in the density of some weed species on maize mulching (Table 3), the number of weed species in the communities did not vary in both crops (Table 5). However, in sorghum the intermediate maize mulch rate of $4 \mathrm{t} \mathrm{ha}^{-1}$ had the least diverse $(P<0.05)$ weed community and the lowest weed species evenness (Table 5). The weed community under the $4 \mathrm{t}$ $\mathrm{ha}^{-1}$ maize mulch rate had a higher proportion of Setaria spp and L. martinicensis which were the two most dominant species in the weed communities under the mulch treatments. These weed species probably took advantage of the improved soil surface conditions for germination under the intermediate mulch rate as reflected by the associated high weed density under this mulch rate (Table 3). The Setaria spp group is one of the worst weed groups in the world and competes for resources efficiently resulting in the exclusion of other weed species (Dekker, 2003).

The low weeding intensity treatment was associated with a significantly $(\mathrm{P}<0.05)$ higher number of weed species than that observed at the high weeding intensity across all the tillage systems in sorghum (Table 5). This suggests that more weed species were able to emerge and grow successfully in the low weeding intensity treatment than in the high weeding intensity treatment. This is consistent with the findings of Legere et al. (2005) who noted that weed diversity indices are more consistently affected by weed management. However, in our study the individual weed species in the weed community under the low weeding intensity treatment were less $(P<0.01)$ evenly distributed resulting in a less diverse weed community (Table 5). The density of abundant weed species such as Setaria spp, $L$. martinicensis and $A$. repens were higher in the low weeding intensity treatment compared to high weeding intensity resulting in these species being more dominant in the low intensity community. The low weeding intensity treatment is a reflection of the current smallholder farmers' weeding practices. The less diverse community under the low weeding intensity treatment may result in weed management problems. According to Miyazawa et al. (2004), high weed community diversity may facilitate weed control in sustainable agriculture by enhancing competition among weed species and preventing the dominance of a single weed species, especially if this is a problem weed in arable fields.

\section{Conclusion}

Weed density and community diversity in the MT systems of planting basin and ripper tine did not vary significantly from that under CONV tillage at Matopos Research Station, even after five or six years. Minimum tillage systems had, however, high numbers of the smallseeded weed species $P$. oleracea in the cowpea phase and $S$. alba in the sorghum phase. The intermediate maize residue rate of $4 \mathrm{t} \mathrm{ha}^{-1}$ had the highest weed density in both crops; the least diverse weed community dominated by Setaria spp and was associated with increased density of aggressive weeds such as $I$. indica. Our findings suggest that moderate mulch rates may exacerbate the weed management problems of small holder farmers. However, the mulch rate of $8 \mathrm{t} \mathrm{ha}^{-1}$ reduced the density of $C$. tridens, $P$. oleraceae, and $E$. prostrata in the sorghum crop. Furthermore, mulching in general for I. plebia and the maize mulch rate of $8 \mathrm{t} \mathrm{ha}^{-1}$ for annual monocots were observed to suppress weed density under the low weeding intensity treatment suggesting that mulching can supplement hoe weeding where frequent weeding is not possible for these weed species. The high hoe weeding intensity treatment reduced weed density and species richness under sorghum, and had a more diverse weed community than the low weeding intensity treatment. The findings of this study suggest that frequent hoe weeding can effectively control weeds even in MT systems. However, this high weeding requirement may ultimately limit the area cropped under MT systems.

\section{ACKNOWLEDGEMENTS}

We would like to thank the Department for International Development of the United Kingdom (DFID-UK), the International Foundation for Science (IFS) and National Research Foundation (NRF, South Africa) for providing funding for this study.

\section{REFERENCES}

Baudron F, Mwanza HM, Tiomphe B, Bwalya M (2007). Conservation agriculture in Zambia: A case study of Southern Province, Nairobi; African Conservation Tillage Network, Centre de Cooperation Internationale de Recherche Agronomique pour le Development, Food and Agriculture Organisation of the United Nations. p. 28.

Booth BD, Swanton CJ (2002). Assembly theory applied to weed community. Weed Sci. 50:2-13.

Chauhan BS, Gill GS, Preston C (2006). Tillage system effects on weed ecology, herbicide activity and persistence: a review. Aust. J. Exp. Agric. 46:1557-1570. 
Chauhan BS, Johnson DE (2009). Seed germination ecology of Portulaca oleracea L.: An important weed of rice and upland crops. Ann. Appl. Biol. 155:61-69.

Christofolleti PJ, De Calvalho SJP, Lopez-Ovejero RF, Nicolai M, Hidalgo E, Da Silva JE (2007). Conservation of natural resources in Brazilian agriculture: Implications on weed biology and management. Crop Prot. 26:383-389.

Dekker J (2003). The foxtail (Setaria) species-group. Weed Sci. 56:699706.

Derpsch R, Friedrich R (2009). Global overview of conservation agriculture adoption. IV World Congress on Conservation Agriculture: Innovations for improving efficiency and equity and environment. New Dehli, India, February 2009, ICAR. pp 4-7. http://www.fao.org/ag/ca.

Dzerefos CM, Shackleon CM, Scholes MC (1994). Seed germination, nitrogen nutrition and water requirements of the edible hern Corchorus tridens (Tiliceae). Econ. Bot. 49:380-386.

Farooq M, Flower KC, Jabran K, Wahid A, Siddique KHM (2011). Crop yield and weed management in rainfed conservation agriculture. Soil Till. Res. 117:172-183.

Food and Agriculture Organisation FAO (2010). http://www.fao.org/ag/ca.

GenStat Release 9.1. Lawes Agricultural Trust. (2006). Rothamstead Experimental Station.

Giller K, Witter E, Corbeels M, Tittonell P (2009). Conservation agriculture and smallholder farming in Africa: the heretic's view. Field. Crop. Res. 114:23-34.

Gianessi L (2009). Solving Africa's weed problem: Increasing crop production and improving the lives of women. Crop Protection Research Institute. CropLife Foundation. www.croplifefoundation.org.

Gomez KA, Gomez AA (1984). Statistical for agricultural research. $\left(2^{\text {nd }}\right.$ Edition). John Wiley \& Sons, New York. p. 680.

Gowing JW, Palmer M (2008). Sustainable agriculture development in sub-Saharan Africa: the case for a paradigm shift in land husbandry. Soil. Use. Manage. 24:92-99.

Legere A, Stevenson FC, Benoit DL (2005). Diversity and assembly of weed community responses across cropping systems. Weed. Res. 45:303-315.

Mabasa S, Riches CR, Nyahunzvu S, Twomlow SJ, Dhliwayo HH, Chatizwa I (1998). Tillage and weed control responses on a semi-arid granitic catena. II Weed responses. Paper presented at CIMMYT $6^{\text {th }}$ Regional Maize Conference for Eastern and Southern Africa. Addis Ababa. 12 p.

Magurran AE (1988). Ecological diversity and its measurement. Princeton University Press. Princeton, New Jersey, p. 179.

Makanganise A, Mabasa S (1999). Field guide to the identification of important weeds of arable lands in Zimbabwe. Department of Research and Specialist Services Publication . Harare, Zimbabwe, p. 41.

Makanganise A, Mabasa, S, Jasi, I, Gatsi T (2001). Verification trials and farmer-managed demonstrations in integrated weed management under different tillage systems and fertility levels in smallholder farming areas of Zimbabwe. Seventh Eastern and Southern Africa Regional Conference. $11^{\text {th }}-15^{\text {th }}$ February, pp. 508512.
Manduna-Madamombe I, Vibrans H, Lopez-Mata L (2008). Diversity of coevolved weeds in smallholder maize fields of Mexico and Zimbabwe. Biodivers. Conserv. 6:1589-1610.

Mashingaidze N, Madakadze C, Twomlow S, Nyamangara J, Hove L (2012). Crop yield and weed growth under conservation agriculture in semi-arid Zimbabwe. Soil Tillage Res. 124:102-110.

Mazvimavi K, Twomlow S (2009). Socioeconomic and institutional factors influencing the adoption of conservation farming by vulnerable households in Zimbabwe. Agr. Syst. 101:20-29.

Miyazawa K, Tsuji H, Yamagata M, Nakano H, Nakamato T (2004). Response of weed flora to combinations of reduced tillage, biocide application and fertilization practices in a 3-year crop rotation. Weed Biol. Manag. 4:24-34.

Moyo M (2001). Representative soil profiles of ICISAT research sites. Chemistry and Soil Research Institute. Soils Report No. A666. AREX, Harare, Zimbabwe, p. 97.

Mupangwa W (2009). Water and nitrogen management for risk mitigation in semi-arid cropping systems. PhD Thesis. University of the Free State, Republic of South Africa. p. 351.

Ncube B (2007). Understanding cropping systems in semi-arid environments of Zimbabwe: options for soil fertility management. PhD Thesis. Wageningen University. The Netherlands. Rupende E, Chivinge OA, Mariga IK (1998). Effect of storage time on weed seedling emergence and nutrient release in cattle manure. Expl. Agric. 34:277-285.

Sanchez P (2002). Soil fertility and hunger in Africa. science 225:20192020.

Sibuga KP (1997). Weed management in Eastern and Southern Africa: Challenges for the $21^{\text {st }}$ century. $16^{\text {th }}$ East African Biennial Weed Science Conference Proceedings. pp. 5-11.

Traore S, Mason SC, Martin AR,Martensen DA,Spotanski JJ (2003). Velvetleaf interference effects on yield and growth of grain sorghum. Agron. J. 95:1602-1607.

Twomlow SJ, Steyn JT, Du Preez CC (2006). Dryland farming in Southern Africa. American Society of Agronomy, Dryland agriculture, $2^{\text {nd }}$ ed., Agron. Monogr. no. 23.

Twomlow SJ, Urolov JC, Oldrieve B, Jenrich M (2008). Lessons from the field - Zimbabwe's Conservation Agriculture Task Force. J.SAT Agr. Res. 6:1-11.

Twomlow S, Hove L, Mupangwa W, Masikati P, Mashingaidze N (2009). Precision Conservation Agriculture For Vulnerable Farmers In LowPotential Zones In Humphreys E, Bayot RS (Editors). Increasing the productivity and sustainability of rainfed cropping systems of poor smallholder farmers. Proceedings of the CGIAR Challenge Program on Water and Food International Workshop on Rainfed Cropping Systems, Tamale, Ghana, 22-25 September 2008. The CGIAR Challenge Program on Water and Food, Colombo, Sri Lanka. pp. 3754.

Vogel H (1994). Weeds in single crop conservation farming in Zimbabwe. Soil Tillage Res. 31:169-185.

Wall PC (2007). Tailoring conservation agriculture to the needs of small farmers in developing countries. J. Crop Impr. 19:137-155. 